Article

|||||||||||||||||||||||||||||||||||||||||||

\title{
Biosorption of Lanthanides Using Three Kinds of Seaweed Biomasses
}

\author{
Nobuo SaKamoto, Naoki Kano*, Yudan W Ang, Lidi Gao and Hiroshi Imaizumi* \\ Graduate School of Science and Technology, Niigata University \\ * Faculty of Engineering, Niigata University \\ 2-8050 Ikarashi, Nishi-ku, Niigata-shi, Niigata Pref. 950-2181, Japan
}

Received May 27, 2010

\begin{abstract}
In order to evaluate the efficiency of seaweed biomass as sorbent for rare earth elements (REEs), sorption experiment from aqueous solutions containing known amount of lanthanide ( $\mathrm{La}, \mathrm{Eu}$ or $\mathrm{Yb}$ ) using three kinds of Ca-loaded dried seaweeds (brown algae : Sargassum hemiphyllum, green algae : Ulva pertusa and red algae : Schizymenia dubyi) in single component system was explored. Furthermore, the sorption mechanism of these elements was investigated by applying Langmuir and Freundlich isotherm equations to the data obtained. In addition, to confirm the characteristics of the seaweed biomasses, the surface morphology of the biomass before and after metal adsorption was determined by Scanning Electron Microscope (SEM).

Consequently, the following matters have been mainly clarified. (1)The morphology of Sargassum hemiphyllum and Ulva pertusa surface has hardly changed even after exposing to metals. On the other hand, the change of the surface condition on Schizymenia dubyi after adsorption was observed. (2) Adsorption isotherms using the seaweed biomass can be described by Langmuir and Freundlich isotherms satisfactorily for lanthanide. These adsorption may have occurred mainly by monolayer reaction because of better-fitting for Langmuir model. (3) The seaweed biomasses could be an efficient sorbent for REEs. Particularly, Ulva pertusa is found to be a promising biosorbent for removing La. (4) Ion-exchange process is considered to be the main mechanism responsible for the sorption of lanthanide ion onto the seaweed biomass.
\end{abstract}

Key Words : biosorption, lanthanide, Sargassum hemiphyllum, Ulva pertusa, Schizymenia dubyi, seaweed biomass

\section{Introduction}

Contamination of toxic metals in the aquatic environment is one of the most debatable problems in the world. Thus, the minimization and recovery of harmful pollutants such as heavy metals in natural environment is very significant $^{1)}$.

Among environmentally friendly technologies for the removal of heavy metals from aquatic effluent, biosorption has attracted increasing research interest recently ${ }^{2,3}$. During past few decades, biosorption studies using various biomasses have been widely performed in large parts of the world ${ }^{3)}{ }^{-10}$. However, a few reports are available on exploration of marine biomasses $^{9,10)}$.

Among many biosorbents, it is considered that marine seaweed is an excellent biosorbent for metals because it is well known to concentrate metals ${ }^{11), 12)}$. Moreover, seaweeds are reported to accumulate hydrocarbons (as well as metals) ; and they are exposed to the ubiquitous presence of organic micropollutants and can work as suitable biomonitors ${ }^{13)}$.

Biosorption studies have been mainly focused on toxic elements such as $\mathrm{Cd}, \mathrm{Pb}, \mathrm{Cu}, \mathrm{As}$ and $\mathrm{Cr}$ for subject elements ${ }^{14}$. In our research, 
the objective elements are mainly rare earth elements (REEs) and uranium (U) from the viewpoint of resources recovery, although REEs do not represent a common toxic threat.

Rare earth elements (REEs) find wide range of applications as functional materials in agriculture and as other industrial products, then the demand of REEs in modern technology has increased remarkably over the past years ${ }^{15), 16)}$. However, the shortage of trace metals including REEs (and the problem of stable supply for these metals) has been concerned in recent years.

In our previous paper ${ }^{17)}$, laboratory model experiment as to uptake of REEs and U using both living and dried samples in two kinds of brown algae (i.e., Sargassum hemiphyllum and Undaria pinnatifida) has been carried out as well as the determination of REEs and $U$ in five kinds of brown algae. Consequently, the following has been mainly obtained: (1) The uptake and/or accumulation mechanism of REEs in brown algae may be different from that of $U$; (2) No large difference of adsorption capacity between $S$. $h$. and $U$. $p$. was observed for REEs and U, although $S$. $h$. showed slightly higher adsorption capacity than $U . p$.

It is known that alginate is an exopolymer extracted mainly from brown algae (and various bacteria) that has been used both as immobilization material and as biosorbent of several heavy metals ${ }^{18)}$. Then, biosorption studies using seaweed have been generally concentrated on brown algae so far ${ }^{19)}$,20). Green and red algae as well as brown algae were also used for biosorbent of REEs in the present work.

In this paper, we present the results of sorption experiment for REEs (three lanthanide elements: $\mathrm{La}, \mathrm{Eu}$ and $\mathrm{Yb}$ ) in single component system using 3 kinds of dried seaweeds (brown algae: Sargassum hemiphyllum, green algae: Ulva pertusa and red algae: Schizymenia dubyi) to investigate the efficiency of seaweed biomass as sorbent for REEs for more practical use in future. Furthermore, sorption isotherms of lanthanides ( $\mathrm{La}, \mathrm{Eu}$ and $\mathrm{Yb}$ ) were studied and analyzed using Langmuir and Freundlich equations.

\section{Experimental}

\section{$2 \cdot 1$ Samples}

Many kinds of seaweeds samples (10 species of green algae, 21 species of brown algae and 21 species of red algae) were taken along several coasts in Niigata Prefecture (referred to Fig. 1 in our previous paper ${ }^{21)}$ since April, 2004. Among seaweed species, the seaweeds for biosorbent used in this work were Sargassum hemiphyllum (brown algae), Ulva pertusa (green algae) and Schizymenia dubyi (red algae). Each seaweed sample was washed in the surrounding seawater to remove attachment at sampling place. After transport back to the laboratory, the seaweed was first washed with tap water and ultrapure water thoroughly and then air-dried for $2-3$ days. Afterwards, it was dried overnight in an electric drying oven (Advantec DRA 430DA) at maximum temperature of $55{ }^{\circ} \mathrm{C}$ to avoid degradation of the binding sites, the biomass was ground. Sizes of biomass ranging from $0.5 \mathrm{~mm}$ to $1 \mathrm{~mm}$ were obtained by passing through sieves (SANPO Test Sieves).

\section{$2 \cdot 2$ Apparatus and Reagents}

An ICP-AES instrument (Seiko Instruments, Inc., SPS1500) was used to determine the concentrations of lanthanides ( $\mathrm{La}, \mathrm{Eu}$ and $\mathrm{Yb}$ ) and calcium (Ca). The operating conditions of the ICP-AES are shown in Table 1 . The surface 
Table 1 Operating conditions of ICP-AES

\begin{tabular}{ll}
\hline Parameters & \\
\hline Plasma conditions & \\
Rf frequency (MHz) & 27.12 \\
Incident power (kw) & 1.3 \\
Gas conditions & \\
Outer gas (Ar) flow rate $\left(\mathrm{dm}^{3} \mathrm{~min}^{-1}\right)$ & 17 \\
Intermediate gas (Ar) flow rate $\left(\mathrm{dm}^{3} \mathrm{~min}^{-1}\right)$ & 0.55 \\
Carrier gas (Ar) flow rate $\left(\mathrm{dm}^{3} \mathrm{~min}^{-1}\right)$ & 0.58 \\
Sampling conditions & \\
Observation height (mm) & 10.3 \\
Integration time (s) & 3 \\
Detection wavelength (nm) & La: 333.749, Eu: 381.967, Yb: 328.937, \\
& Ca: 393.366 \\
\hline
\end{tabular}

morphology of each biomass (before and after metal adsorption) was determined by SEM (Scanning Electron Microscope; JEOL, JSM5800). The measurement of $\mathrm{pH}$ in solution was carried out using a pH meter (HORIBA, F-21).

For biosorption experiment, solution containing each lanthanide ( $\mathrm{La}, \mathrm{Eu}$ or $\mathrm{Yb}$ ) was individually prepared using each nitrate salt: $\mathrm{La}\left(\mathrm{NO}_{3}\right)_{3} \cdot 6 \mathrm{H}_{2} \mathrm{O}, \mathrm{Eu}\left(\mathrm{NO}_{3}\right)_{3} \cdot 6 \mathrm{H}_{2} \mathrm{O}$, or $\mathrm{Yb}\left(\mathrm{NO}_{3}\right)_{3}$. $3 \mathrm{H}_{2} \mathrm{O}$ supplied by Kishida Kagaku Company. The solution for loading $\mathrm{Ca}$ on each biomass was prepared by using $\mathrm{Ca}\left(\mathrm{NO}_{3}\right)_{2} \cdot 4 \mathrm{H}_{2} \mathrm{O}$ (supplied by Kanto Chemical Co.). Lanthanide standard solutions used for making the calibration curve were prepared by diluting the standard solutions (XSTC-1 for REEs ; $10 \mathrm{mg} \cdot \mathrm{dm}^{-3}$ in $5 \%$ $\mathrm{HNO}_{3}$ solution) purchased from SPEX CertiPrep, Inc. (USA); and Ca standard solution used for calibration curve was prepared by diluting the standard solution (Kanto Chemical Co. $; 1000 \mathrm{mg} \cdot \mathrm{dm}^{-3} \mathrm{CaCO}_{3}$ in $0.1 \mathrm{~mol} \cdot \mathrm{dm}^{-3}$ $\mathrm{HNO}_{3}$ solution).

All other chemical reagents were purchased from Kanto Chemical Co., Inc. (Japan). All reagents used were of analytical grade, and water $(>18.2 \mathrm{M} \Omega)$ which was treated by an ul- trapure water system (Advantec aquarius: RFU 424TA) was employed throughout the work.

\section{$2 \cdot 3$ Pretreatment of biomass}

Based on Diniz and Volesky's study ${ }^{20)}$, each sieved biomass sample (prepared in Sec. $2 \cdot 1$ ) was loaded with $\mathrm{Ca}^{2+}$ in a solution of 50 $\mathrm{mmol} \cdot \mathrm{dm}^{-3} \mathrm{Ca}\left(\mathrm{NO}_{3}\right)_{2}$ (biomass concentration of $10 \mathrm{~g} \cdot \mathrm{dm}^{-3}$ ) for $24 \mathrm{~h}$ under gentle agitation in order to remove the original cations on seaweed. Later, the biomass was washed with ultrapure water to remove excess $\mathrm{Ca}^{2+}$ until the mixture was reached approximately $\mathrm{pH}$. Finally, the washed biomass was dried again overnight at $50{ }^{\circ} \mathrm{C}$ in an electric drying oven, and stored in desiccators (containing silica gel as a desiccant) before use.

$2 \cdot 4$ Sorption experiment for lanthanides ( $\mathrm{La}, \mathrm{Eu}$ and $\mathrm{Yb}$ ) using seaweed biomass

The following sorption experiments were performed using Ca-loaded seaweed biomass. Samples of $0.4 \mathrm{~g}$ of the biomass were contacted with $200 \mathrm{~cm}^{3}$ of solution containing known initial each lanthanide ( $\mathrm{La}$, Eu or $\mathrm{Yb}$ ) concentra- 
tion ranging from 0.1 to $4 \mathrm{mmol} \cdot \mathrm{dm}^{-3}$. Afterwards, the suspensions were shaken for $24 \mathrm{~h}$ in a water bath at ambient temperature $(\sim 25$ ${ }^{\circ} \mathrm{C}$ ) at $\mathrm{pH}$ 4. Experimental conditions (i.e., $\mathrm{pH}$, contact time and biosorbent dose rate) in this work were determined based on our preliminary experiments and other literatures ${ }^{14), 20,22 \text { ). }}$ The $\mathrm{pH}$ of each solution was adjusted by using $0.1 \mathrm{~mol} \cdot \mathrm{dm}^{-3} \mathrm{HNO}_{3}$.

Following with each sorption experiment, the suspension containing biomass and each lanthanide (La, Eu or $\mathrm{Yb}$ ) solution was filtered, and the concentration of each lanthanide in the filtrate (along with the amount of $\mathrm{Ca}^{2+}$ released from the biomass) was determined with an ICP-AES.

The metal uptake by the seaweeds was calculated using the following mass balance equa$\operatorname{tion}^{23)}$ :

$$
q=\left(C_{i}-C_{f}\right) V / W\left[\mathrm{mg} \cdot \mathrm{g}^{-1}\right]
$$

where $q=$ metal uptake $\left(\mathrm{mmol} \cdot \mathrm{g}^{-1}\right) ; C_{i}=$ initial metal concentration $\left(\mathrm{mmol} \cdot \mathrm{dm}^{-3}\right) ; C_{f}=$ equilibrium metal concentration $\left(\mathrm{mmol} \cdot \mathrm{dm}^{-3}\right) ; V=$ volume of the solution $\left(\mathrm{dm}^{3}\right)$; and $W=$ dry mass of seaweed $(\mathrm{g})$.

The removal efficiency (RE, \%) of the biosorbent on the metal in the solution was determined by the following equation ${ }^{14)}$ :

$$
\mathrm{RE}=\left(C_{i}-C_{f}\right) \times 100 / C_{i}
$$

To evaluate the release of excess $\mathrm{Ca}$ from the biomass in the water, the following blank experiment was also carried out using Caloaded seaweed biomass and ultrapure water without any spiked metals. The biomass was contacted with $200 \mathrm{~cm}^{3}$ of ultrapure water (controlled at $\mathrm{pH} 4.0$ by adding $0.1 \mathrm{~mol} \cdot \mathrm{dm}^{-3}$ $\mathrm{HNO}_{3}$ ), and the suspension was shaken in a water bath at ambient temperature $\left(25{ }^{\circ} \mathrm{C}\right)$ for
$24 \mathrm{~h}$. Afterwards, the supernatant was retrieved and analyzed for $\mathrm{Ca}$ concentration. Thus, the net $\mathrm{Ca}^{2+}$ concentration released from the biomass in the sorption experiment was obtained by subtracting the above-mentioned "excess Ca" concentration (as blank) from the total $\mathrm{Ca}$ released when these metals were present.

2.5 Langmuir and Freundlich isotherm model

Langmuir adsorption isotherm model was applied based on Tsui et al. ${ }^{14)}$ to fit the adsorption data obtained in this study. Langmuir model assumes monolayer sorption onto a surface and is given as below.

$$
q=\left(q_{\mathrm{e}} \times C_{f}\right) /\left(A^{-1}+C_{f}\right)
$$

where $q_{\mathrm{e}}=$ maximum metal uptake $\left(\mathrm{mmol} \cdot \mathrm{g}^{-1}\right)$ (i.e., the maximum attainable binding capacity) ; and $A=$ affinity constant $\left(1 \mathrm{mmol}^{-1}\right)$ (i.e., the affinity of the metal ion toward the biomass). These two parameters can reflect the nature of the sorbent material and can compare the biosorption performance.

Freundlich isotherm model was also applied based on Dahiya et al. ${ }^{9)}{ }^{10)}$ to evaluate the adsorption data. The Freundlich equation is widely used in the field of environmental engineering. Freundlich isotherm can also be used to explain adsorption phenomenon as given below.

$$
q_{e}=K_{F} C_{f}^{1 / n}
$$

where $K_{\mathrm{F}}$ and $n$ are constants incorporating all factors affecting the adsorption capacity and an indication of the favorability of metal ion adsorption onto biosorbent, respectively. It is shown that $1 / n$ values between 0.1 and 1.0 correspond to beneficial adsorption. The linearized 
(a)

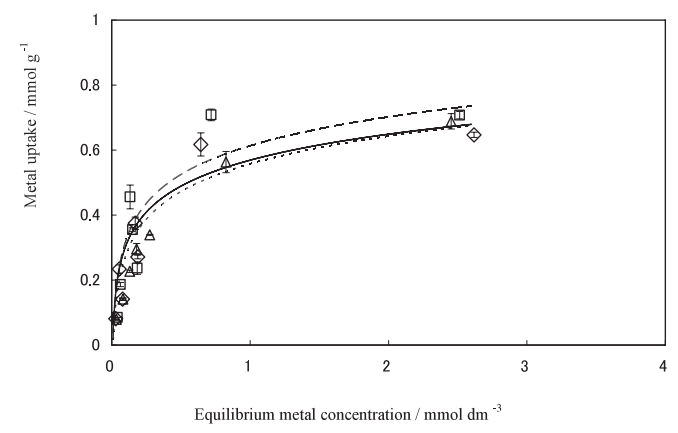

(b)

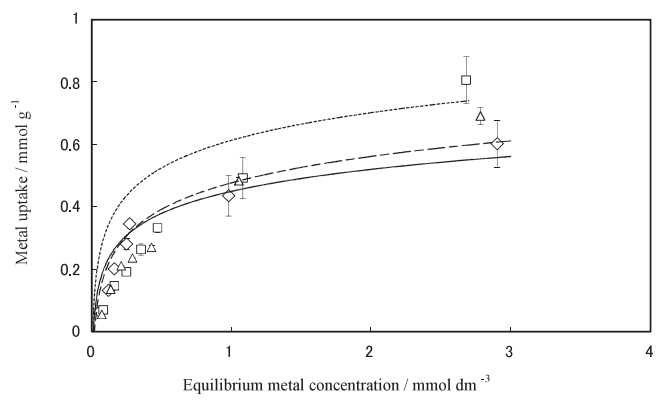

(c)

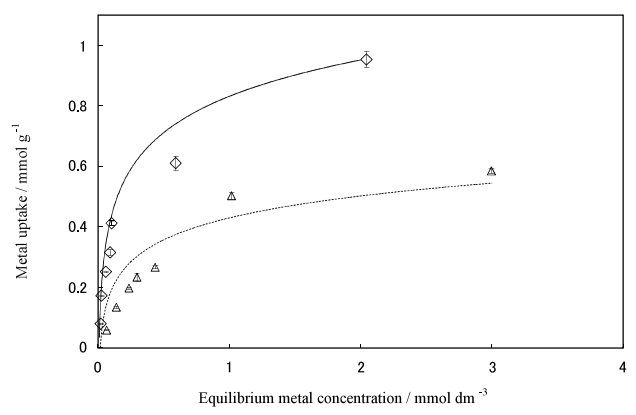

Fig. 1 Sorption isotherms of $\mathrm{La}(\diamond), \mathrm{Eu}(\square)$ and $\mathrm{Yb}(\triangle)$ by three kinds of Ca-loaded seaweed biomasses at $\mathrm{pH}$ 4.0,(a) : Sargassum hemiphyllum, (b) : Schizymenia duby and (c) : Ulva pertusa. The curves obtained from non-linear regression of the data by Langmuir isotherm are also shown (La: solid curve, Eu: broken curve and $\mathrm{Yb}$ : dotted curve). Data are mean \pm standard deviation $(\mathrm{n}=3)$.

Freundlich model isotherm is represented by the following equation :

$$
\log _{10} q_{e}=\log _{10} K_{F}+(1 / n) \log _{10} C_{f}
$$

That is, $q_{e}$ versus $C_{f}$ in log scale can be plotted to determine values of $1 / n$ and $K_{\mathrm{F}}$.

\section{Results and discussion}

\subsection{Metal sorption capacity at different species}

The equilibrium sorption isotherms of $\mathrm{La}, \mathrm{Eu}$ and $\mathrm{Yb}$ by three kinds of Ca-loaded seaweed biomasses at $\mathrm{pH} 4$ are shown in Fig. 1((a): Sargassum hemiphyllum, (b) : Schizymenia dubyi, (c) : Ulva pertusa). Sorption experiment of Eu using $U$. $p$. biomass could not be conducted due to the lack of sample in this work. The adsorption data obtained in this work were analyzed using Langmuir and Freundlich equations. The correlation coefficients $\left(R^{2}\right)$ of Langmuir and Freundlich isotherms for $\mathrm{La}, \mathrm{Eu}$ and $\mathrm{Yb}$ using three kinds of Ca-loaded seaweed biomasses are shown in Table 2 along with other parameters.

From this table, it is found that $R^{2}$ value for each datum is comparatively large for both Langmuir and Freundlich isotherms. The value of $1 / n$ less than unity indicates better adsorption and formation of relatively stronger bonds between adsorbent and adsorbate ${ }^{9)}$. That is to 
Table 2 Langmuir and Freundlich parameters for biosorption of lanthanides on three kinds of Ca-loaded biomasses at $\mathrm{pH} 4.0$

\begin{tabular}{ccccccccccc}
\hline & \multicolumn{1}{c}{ Sargassum hemiphyllum } & \multicolumn{3}{c}{ Schizymenia dubyi } & \multicolumn{3}{c}{ Ulva pertusa } \\
\cline { 2 - 10 } & $\mathrm{La}$ & $\mathrm{Eu}$ & $\mathrm{Yb}$ & $\mathrm{La}$ & $\mathrm{Eu}$ & $\mathrm{Yb}$ & $\mathrm{La}$ & $\mathrm{Eu}$ & $\mathrm{Yb}$ \\
\hline Langmuir & & & & & & & & & \\
$q_{e} / \mathrm{mmol} \mathrm{g}^{-1}$ & 0.700 & 0.781 & 0.769 & 0.651 & 0.980 & 0.926 & 0.930 & --- & 0.719 \\
$A / \mathrm{mmol}^{-1}$ & 5.19 & 4.33 & 3.03 & 2.53 & 1.05 & 1.08 & 6.03 & --- & 1.59 \\
$R^{2}$ & 0.992 & 0.987 & 0.999 & 0.982 & 0.969 & 0.983 & 0.996 & -- & 0.991 \\
\hline Freundlich & & & & & & & & & & \\
$K_{F} / \mathrm{g}^{-1}$ & 0.575 & 0.648 & 0.561 & 0.450 & 0.475 & 0.443 & 0.816 & -- & 0.409 \\
$1 / n$ & 0.440 & 0.462 & 0.500 & 0.531 & 0.683 & 0.646 & 0.461 & --- & 0.595 \\
$R^{2}$ & 0.806 & 0.731 & 0.937 & 0.839 & 0.969 & 0.923 & 0.878 & --- & 0.923 \\
\hline
\end{tabular}

--- represents the defect of data due to the lack of sample

say, favorable adsorption for $\mathrm{La}, \mathrm{Eu}$ and $\mathrm{Yb}$ by these seaweed biomasses used in this work is presented. Furthermore, it is noted that $R^{2}$ values for these data are particularly large for Langmuir isotherm than for Freundlich isotherm $(0.969-0.999$ for Langmuir isotherm and $0.731-0.969$ for Freundlich one). This result suggests that the adsorption on these samples mainly occurred by monolayer reaction. Therefore, the curves obtained from non-linear regression of the data by Langmuir isotherm are also shown in Fig. 1 (solid curve for La, broken curve for $\mathrm{Eu}$, and dotted curve for $\mathrm{Yb}$ ).

From Table 2, it is found that the data of $q_{\mathrm{e}}$ for $\mathrm{Eu}$ and $\mathrm{Yb}$ by Sargassum hemiphyllum (brown algae) obtained in this study are similar to the result of species of Sargassum conducted by Diniz and Volesky ${ }^{20}$, although $q_{\mathrm{e}}$ for $\mathrm{La}$ is slightly small. Moreover, it is noteworthy that both Langmuir parameters: $q_{\mathrm{e}}$ and $A$ for La by Ulva pertusa (green algae) is considerably large. Then, the comparison of sorption isotherms of La among three kinds of seaweed biomasses is shown in Fig. 2. From this figure, the sorption capacity of La by $U$. $p$. (green algae) is fairly large compared to that by other algae : $S . h$. (brown algae) and $S . d .($ red algae). It is generally known that brown seaweed is superior to red and green seaweed in metal sorption capacity for heavy metals such as $\mathrm{Cd}$, $\mathrm{Pb}, \mathrm{Cu}^{24), 25)}$; and such a high value of $q_{\mathrm{e}}$ (as observed in this work) using green algae have not been reported so far. In other words, it is significant outcome to find that Ulva pertusa (green algae) can be a promising biosorbent for removing La.

According to our previous work ${ }^{21}$, in case of $\mathrm{U}$, the mean concentration is the highest in brown algae and is the lowest in green algae among phyla (i.e., green, red and brown algae). However, as for the mean concentration of light REE (LREE) such as La, a slightly higher concentration is found in green algae; whereas the concentration of heavy REE (HREE) such as $\mathrm{Yb}$ or $\mathrm{Lu}$ in green algae is smaller than that in brown algae (as shown in Fig. 2 in our previous paper ${ }^{21)}$ ).

Then, large sorption capacity of La by Ulva pertusa may be related to the character (or the constituent) of green algae; and it is possible that "La adsorption on Ulva pertusa" is due to "metal-specific", although further studies is 


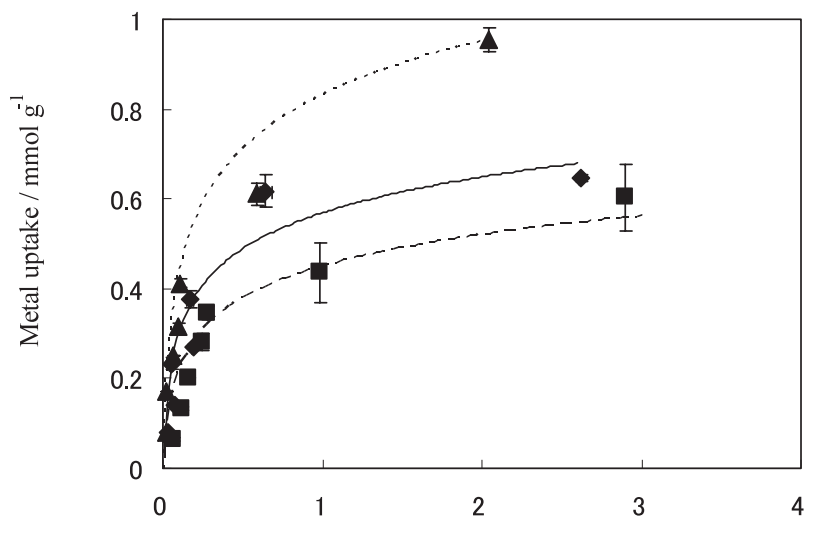

Equilibrium metal concentration $/ \mathrm{mmol} \mathrm{dm}^{-3}$

Fig. 2 Comparison of sorption isotherms for La among three kinds of Ca-loaded seaweed biomasses at $\mathrm{pH} 4.0$,

Sargassum hemiphyllum, $\mathbf{\square}$ : Schizymenia duby, $\mathbf{\Delta}$ : Ulva pertusa. The curves obtained from non-linear regression of the data by Langmuir isotherm are also shown (S.h.: solid curve, S. $d$.: broken curve and $U . p$. : dotted curve). Data are mean \pm standard deviation $(n=3)$.

needed to confirm the peculiarity by investigating the other combinations of metals and seaweed species.

SEM pictures of three kinds of Ca-loaded seaweed biomasses ( (a): Sargassum hemiphyllum, (b) : Schizymenia dubyi, and (c) : Ulva pertusa) before and after adsorption of lanthanum are shown in Fig. 3 and Fig. 4, respectively.

According to SEM observation, the surface of $S$. $d$.(red algae) seems to be relatively flat, whereas $S$. h. (brown algae) and $U . p$. (green algae) have more extensive surface area, although the specific surface area of these seaweed biomasses could not be measured due to their small specific surface area. Furthermore, by comparing SEM pictures in Fig. 3 with that in Fig. 4, it is found that the morphology of $S . h$. and $U . p$. surface has hardly changed even after exposing lanthanum. On the other hand, the distinct change of the surface morphology on $S . d$. was observed after adsorption of metals.
From the above observation, two kinds of biomass : Sargassum hemiphyllum and Ulva pertusa should be predicted to withstand the repeated use ; and hence it can be a good adsorbent for lanthanides.

$3 \cdot 2$ Removal efficiency and binding mechanism

The removal efficiency (RE) of 3 kinds of seaweed biomasses as a function of initial metal concentrations $(\mathrm{Ci})$ for 3 lanthanides is shown in Fig. 5 ( (a) : La, (b) : Eu, (c) : Yb). With increasing $\mathrm{Ci}$, the RE generally decreased exponentially ; and at high $C i$, similar RE (i.e., about 40\%) occurred for each lanthanide even with any biomass. These data are well fitted into an exponential function $\left(R^{2}\right.$ ranging from 0.866 to 0.994) shown in Fig. 5 ; and the equations and $R^{2}$ for each lanthanide in each biomass are shown in Table 3.

From the viewpoint of recovering trace met- 
(a)

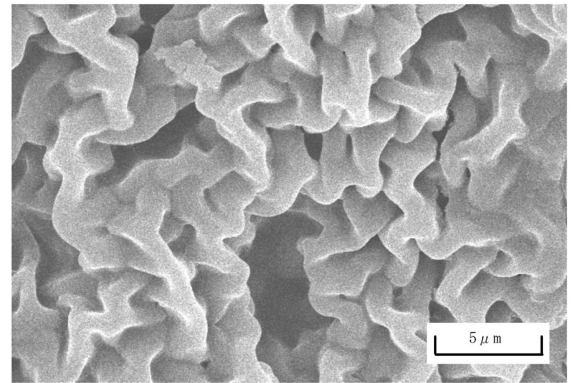

(b)

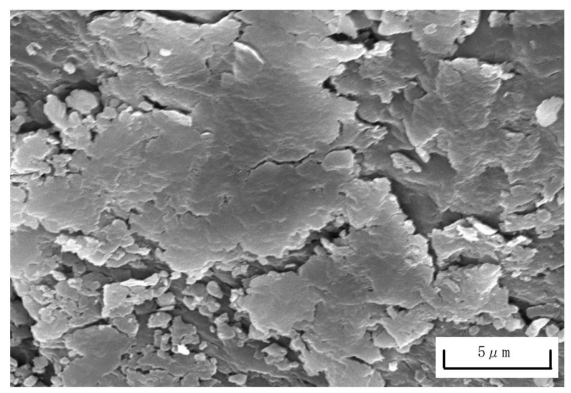

(c)

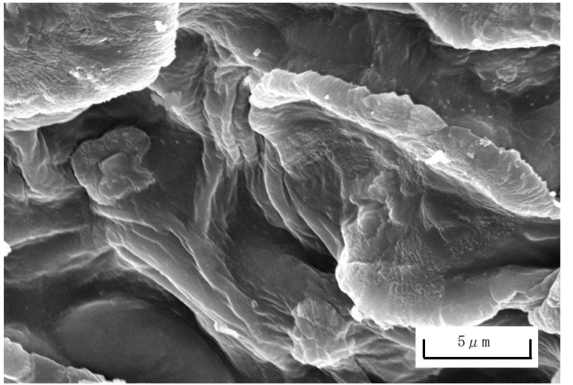

Fig. 3 SEM pictures of seaweed biomasses before adsorption of lanthanum, (a) : Sargassum hemiphyllum, (b) : Schizymenia duby and (c) : Ulva pertusa. (a)

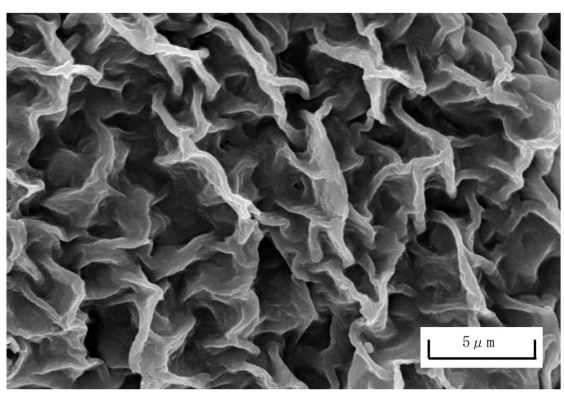

(b)

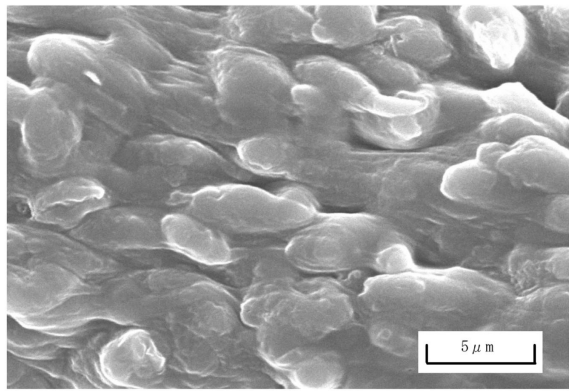

(c)

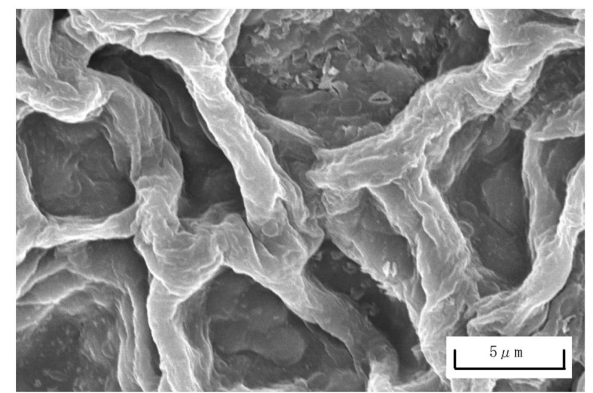

Fig. 4 SEM pictures of seaweed biomasses after adsorption of lanthanum, (a) : Sargassum hemiphyllum, (b) : Schizymenia duby and (c) : Ulva pertusa.

Table 3 Equations and correlation coefficients $\left(R^{2}\right)$ to describe the relationships between removal efficiency (RE) and initial concentrations $(\mathrm{Ci})$ of different lanthanides in the sorption system

\begin{tabular}{|c|c|c|c|c|c|c|}
\hline & \multicolumn{2}{|c|}{ Sargassum hemiphyllum } & \multicolumn{2}{|c|}{ Schizymenia dubyi } & \multicolumn{2}{|l|}{ Ulva pertusa } \\
\hline & Equation & $R^{2}$ & Equation & $R^{2}$ & Equation & $R^{2}$ \\
\hline $\mathrm{La}$ & $\mathrm{RE}=91.4 \exp (-0.239 C i)$ & 0.939 & $\mathrm{RE}=78.7 \exp (-0.241 C i)$ & 0.939 & $\mathrm{RE}=98.5 \exp (-0.191 C i)$ & 0.993 \\
\hline $\mathrm{Eu}$ & $\mathrm{RE}=94.3 \exp (-0.223 C i)$ & 0.866 & $\mathrm{RE}=66.2 \exp (-0.136 C i)$ & 0.973 & ----------- & -- \\
\hline $\mathrm{Yb}$ & $\mathrm{RE}=88.9 \exp (-0.234 C i)$ & 0.994 & $\mathrm{RE}=68.2 \exp (-0.173 C i)$ & 0.944 & $\mathrm{RE}=70.3 \exp (-0.213 \mathrm{Ci})$ & 0.975 \\
\hline
\end{tabular}

--- represents the defect of data due to the lack of sample 
(a)

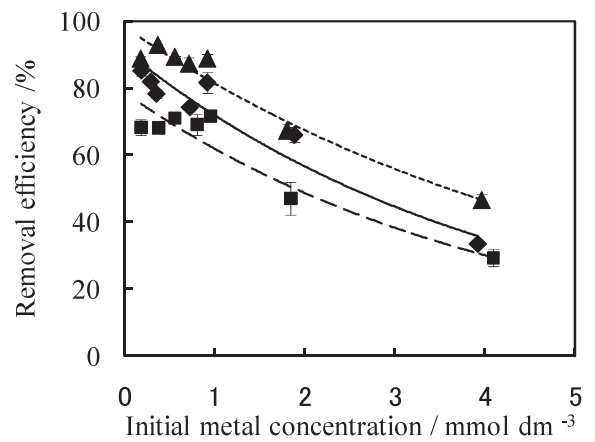

(b)

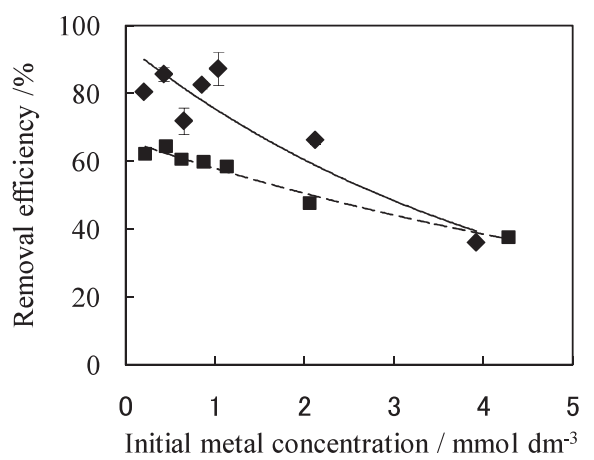

(c)

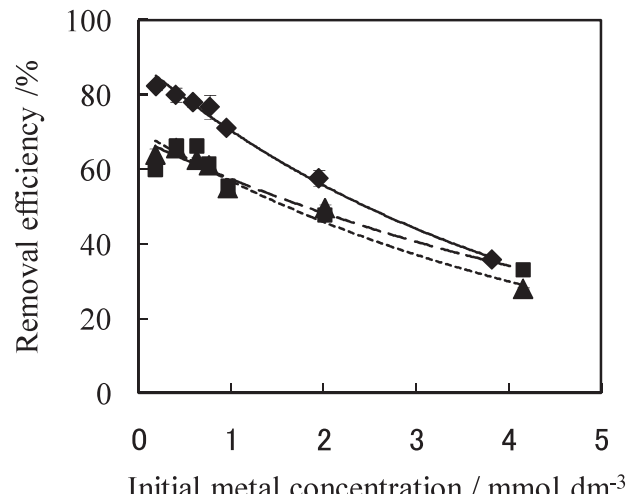

Fig. 5 Removal efficiency of lanthanides ( (a) : La, (b) : Eu, (c) : Yb) by Ca-loaded seaweed biomasses at different initial concentrations,

$\checkmark$ : Sargassum hemiphyllum, $\mathbf{\square}$ : Schizymenia duby, $\boldsymbol{\Delta}$ : Ulva pertusa. Each exponential function is also $\operatorname{shown}(S . h$. : solid curve, $S$. d.: broken curve and U.p.: dotted curve). Data are mean \pm standard deviation $(n=3)$. (a)

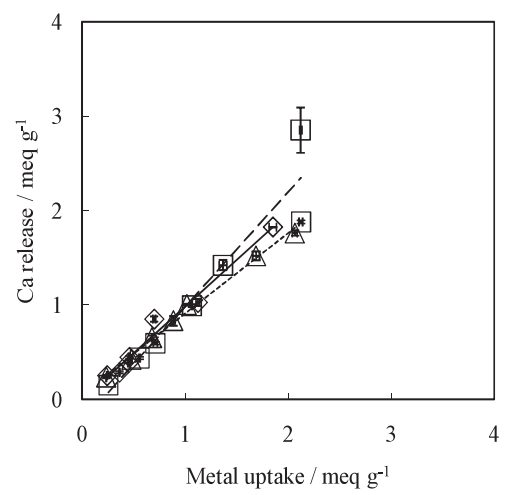

(b)

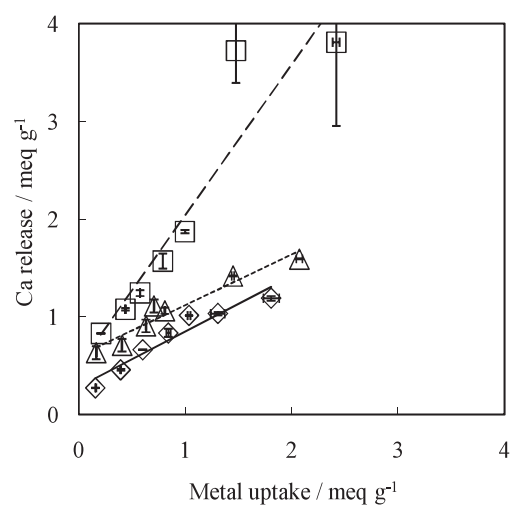

(c)

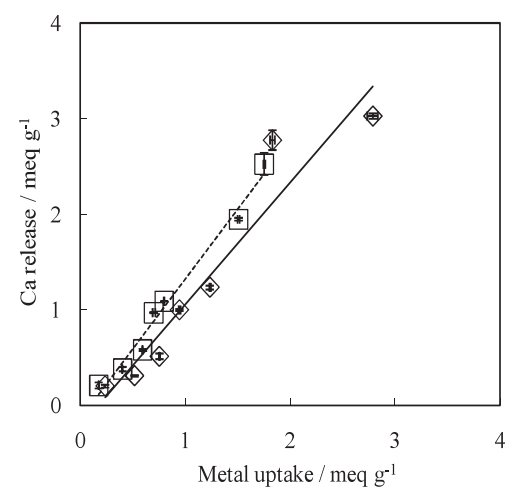

Fig. 6 Relationship between metal uptake and $\mathrm{Ca}$ release from Ca-loaded seaweed biomasses, (a) : Sargassum hemiphyllum, (b) : Schizymenia duby and (c) : Ulva pertusa, $\diamond: \mathrm{La}, \square: \mathrm{Eu}, \triangle$ : Yb. Each regression line is also shown $(\mathrm{La}$ : solid line, Eu:broken line and $\mathrm{Yb}$ : dotted line). Data are mean \pm standard deviation $(n=3)$. 
Table 4 Amount of adsorbed lanthanide and released Ca by Ca-loaded Sargassum hemiphyllum biomass

\begin{tabular}{|c|c|c|c|c|}
\hline \multicolumn{5}{|c|}{ Sargassum hemiphyllum } \\
\hline & $\begin{array}{l}\text { Adsorbed } \\
\text { lanthanide } \\
/ \mathrm{mmol} \mathrm{g}^{-1}\end{array}$ & $\begin{array}{c}\text { Total } \\
\text { Released Ca } \\
/ \mathrm{mmol} \mathrm{g}^{-1} \\
\end{array}$ & $\begin{array}{c}\text { Ca excess } \\
\text { (blank) } \\
/ \mathrm{mmol} \mathrm{g}^{-1} \\
\end{array}$ & $\begin{array}{c}\text { Net } \\
\text { Released Ca } \\
/ \mathrm{mmol} \mathrm{g}^{-1} \\
\end{array}$ \\
\hline \multirow[t]{7}{*}{$\mathrm{La}$} & 0.081 & 0.208 & 0.082 & 0.126 \\
\hline & 0.121 & 0.226 & 0.082 & 0.144 \\
\hline & 0.150 & 0.276 & 0.082 & 0.194 \\
\hline & 0.153 & 0.305 & 0.082 & 0.224 \\
\hline & 0.234 & 0.507 & 0.082 & 0.426 \\
\hline & 0.375 & 0.595 & 0.082 & 0.514 \\
\hline & 0.617 & 0.995 & 0.082 & 0.913 \\
\hline \multirow[t]{7}{*}{$\mathrm{Eu}$} & 0.085 & 0.155 & 0.080 & 0.075 \\
\hline & 0.186 & 0.298 & 0.080 & 0.218 \\
\hline & 0.237 & 0.377 & 0.080 & 0.297 \\
\hline & 0.355 & 0.576 & 0.080 & 0.496 \\
\hline & 0.456 & 0.791 & 0.080 & 0.711 \\
\hline & 0.707 & 1.021 & 0.080 & 0.941 \\
\hline & 0.708 & 1.507 & 0.080 & 1.427 \\
\hline \multirow[t]{7}{*}{$\mathrm{Yb}$} & 0.079 & 0.194 & 0.077 & 0.117 \\
\hline & 0.160 & 0.288 & 0.077 & 0.211 \\
\hline & 0.227 & 0.403 & 0.077 & 0.326 \\
\hline & 0.296 & 0.494 & 0.077 & 0.417 \\
\hline & 0.339 & 0.579 & 0.077 & 0.502 \\
\hline & 0.563 & 0.838 & 0.077 & 0.761 \\
\hline & 0.688 & 0.958 & 0.077 & 0.881 \\
\hline
\end{tabular}

als from aqueous environment such as seawater, the removal efficiency at low concentration of metal is particularly important. The coefficient before exponential function in each equation in Table 3 (i.e., the y-intercept of the exponential functional curve in Fig. 5) represents the value of $\mathrm{RE}$ at low $\mathrm{Ci}$ near approximately zero $\mathrm{mmol} \cdot \mathrm{dm}^{-3}$. From Table 3, the coefficient for each lanthanide in Sargassum hemiphyllum and especially that for La in Ulva pertusa is large. This implies that $U$. p. could be an effi- cient adsorbent for La as well as $S$. $h$. for lanthanides in aqueous environment such as seawater.

The amount $(\mathrm{mmol} \cdot \mathrm{g})$ of adsorbed lanthanide and released $\mathrm{Ca}$ from three kinds of $\mathrm{Ca}$ loaded seaweed biomass is shown in Table 4 6 (Table 4: Sargassum hemiphyllum, Table 5: Schizymenia dubyi, and Table 6: Ulva pertusa). Based on the data in these tables, relationship between the uptake of each lanthanide ion and calcium ion released from each biomass is 
Table 5 Amount of adsorbed lanthanide and released $\mathrm{Ca}$ by Ca-loaded Schizymenia dubyi biomass

\begin{tabular}{cc|ccc}
\hline \multicolumn{4}{c}{ Schizymenia dubyi } \\
\hline & $\begin{array}{c}\text { Adsorbed } \\
\text { lanthanide }\end{array}$ & $\begin{array}{c}\text { Total } \\
\text { Released Ca } \\
/ \mathrm{mmol} \mathrm{g}^{-1}\end{array}$ & $\begin{array}{c}\text { Ca excess } \\
\text { (blank) }\end{array}$ & $\begin{array}{c}\text { Net } \\
\text { Released Ca } \\
/ \mathrm{mmol} \mathrm{g}^{-1}\end{array}$ \\
\hline $\mathrm{La}$ & 0.053 & 0.376 & 0.240 & 0.136 \\
& 0.132 & 0.469 & 0.240 & 0.229 \\
& 0.201 & 0.571 & 0.240 & 0.331 \\
& 0.281 & 0.657 & 0.240 & 0.417 \\
& 0.346 & 0.747 & 0.240 & 0.507 \\
& 0.436 & 0.757 & 0.240 & 0.517 \\
& 0.603 & 0.835 & 0.240 & 0.595 \\
\hline 0.070 & 0.655 & 0.240 & 0.415 \\
\hline 0.146 & 0.778 & 0.240 & 0.538 \\
& 0.192 & 0.862 & 0.240 & 0.622 \\
& 0.263 & 1.025 & 0.240 & 0.785 \\
& 0.333 & 1.176 & 0.240 & 0.936 \\
& 0.493 & 2.102 & 0.240 & 1.862 \\
0.807 & 2.146 & 0.240 & 1.906 \\
\hline 0.055 & 0.557 & 0.240 & 0.317 \\
& 0.136 & 0.594 & 0.240 & 0.354 \\
0.210 & 0.694 & 0.240 & 0.454 \\
0.236 & 0.796 & 0.240 & 0.556 \\
0.270 & 0.771 & 0.240 & 0.531 \\
& 0.483 & 0.950 & 0.240 & 0.710 \\
& 0.691 & 1.036 & 0.240 & 0.796 \\
\hline $\mathrm{Yb}$ & & &
\end{tabular}

shown both in terms of meq $\cdot \mathrm{g}^{-1}$ in Fig. 6 ( (a) : $\mathrm{La},(\mathrm{b}): \mathrm{Eu},(\mathrm{c})$ : Yb). Good and linear relationship is generally found for these samples between the uptake of each lanthanide and Ca released from these biomasses into the solution as shown in Fig. 6. Particularly, in case of $S$. $h$. and $U$. $p$., the slope of the line is about one with the y-intercept of the graphs almost passes through the origin. It indicates that ion-exchange process is found to be the main mechanism responsible for the sorption of lanthanide ion onto the seaweed as Tsui et al. ${ }^{14)}$ and Diniz $\&$ Volesky ${ }^{20)}$ also pointed.

From this work, it was quantitatively clarified to some extent that seaweed biomass could be an efficient sorbent for lanthanides, and exhibit high ability of chemical adsorption. Particularly, Ulva pertusa is found to be a promising biosorbent for removing La. It is also suggested that the adsorption on seaweed biomass is mainly due to monolayer sorption because of well-fitting for Langmuir model. 
Table 6 Amount of adsorbed lanthanide and released Ca by Ca-loaded Ulva pertusa biomass

\begin{tabular}{cc|ccc}
\hline \multicolumn{4}{c}{ Ulva pertusa } \\
\hline & $\begin{array}{c}\text { Adsorbed } \\
\text { lanthanide } \\
/ \mathrm{mmol} \mathrm{g}^{-1}\end{array}$ & $\begin{array}{c}\text { Total } \\
\text { Released Ca } \\
/ \mathrm{mmol} \mathrm{g}^{-1}\end{array}$ & $\begin{array}{c}\text { Ca excess } \\
\text { (blank) } \\
/ \mathrm{mmol} \mathrm{g}^{-1}\end{array}$ & $\begin{array}{c}\text { Net } \\
\text { Released Ca } \\
/ \mathrm{mmol} \mathrm{g}^{-1}\end{array}$ \\
\hline $\mathrm{La}$ & 0.079 & 0.259 & 0.160 & 0.099 \\
& 0.172 & 0.314 & 0.160 & 0.154 \\
& 0.251 & 0.415 & 0.160 & 0.255 \\
& 0.315 & 0.658 & 0.160 & 0.498 \\
& 0.412 & 0.776 & 0.160 & 0.616 \\
& 0.610 & 1.546 & 0.160 & 1.386 \\
& 0.929 & 1.672 & 0.160 & 1.512 \\
\hline 0.059 & 0.263 & 0.160 & 0.103 \\
& 0.134 & 0.349 & 0.160 & 0.189 \\
& 0.198 & 0.449 & 0.160 & 0.289 \\
0.234 & 0.644 & 0.160 & 0.484 \\
0.266 & 0.704 & 0.160 & 0.544 \\
0.503 & 1.132 & 0.160 & 0.972 \\
0.584 & 1.421 & 0.160 & 1.261 \\
\hline
\end{tabular}

The data obtained and the method used in this work can be useful tool from the viewpoint of resource recovery in future work.

\section{Acknowledgements}

The present work was partially supported by a Grant-in-Aid for Scientific Research of the Japan Society for the Promotion of Science, and by Takahashi Industry Economy Research Foundation.

We wish to express our thanks to Dr. M. Baga of the Marine Ecology Research Institute and Dr. R. Ishikawa of Niigata Prefectural Fisheries and Marine Research Institute for giving helpful advice concerning sampling, identification and pretreatment of seaweed. The authors are also grateful to Dr. K. Satoh of Fac. of Sci., M. Ohizumi of Waste Fluid Treatment Facili- ties and Mr. N. Saito of Fac. of Eng. in Niigata University for permitting the use of instrument and facilities and for giving helpful advice in measurement.

\section{References}

1) Saether, O. M., Storroe, G., Segar, D. and Krog, R., Appl. Geochem., 12, 327-332 (1997)

2) Chen, J., Bioresource Technology, 60, 185-189 (1997)

3) Mohantly, K., Jha, M., Meikap, B. C. and Biswas, M. N., Chem. Eng. J., 117, 71-77 (2006)

4) Periasamy, K. and Namasivayam, C., Chemosphere, 32, 769-789 (1996)

5) Acosta, R. I., Rodriguez, X., Gutierrez, C. and de Guadalupe Moctezuma, M., Bioinorg. Chem. Application, 2, 1-7 (2004)

6) Can, Y. M., Kaya, Y. and Algur, F. O., Bioresour. Technol., 97, 1761-1765 (2006) 
7) Conard, K. and Hansen, H. C. B., Bioresour. Technol ., 98, 89-97 (2007)

8) Sharma, P., Kumari, P., Srivastava, M. M. and Srivastava, S., Bioresour. Technol., 98, 474-477 (2007)

9) Dahiya, S., Tripathi, R. M. and Hegde, A. G., Bioresour. Technol., 99, 179-187 (2008)

10) Dahiya, S., Tripathi, R. M. and Hegde, A. G., $J$. Hazard. Mater., 150, 376-386 (2008)

11) Sakao, S., Ogawa, Y. and Uchida, H., Anal. Chim. Acta, 355, 121-127 (1997)

12) Fu, F. F., Akagi, T., Yabuki, S., Iwaki, M. and Ogura, N., J. Phycol ., 36, 62-70 (2000)

13) Crespo, M .O. P. and Yusty, M. A. L., Ecotoxicol. Environ. Saf., 64, 400-405(2006)

14) Tsui, M. T. K., Cheung, K. C., Tam, N. F. Y. and Wong, M. H., Chemosphere, 65, 51-57 (2006)

15) Bahramifar, N. and Yamini, Y., Anal. Chim. Acta, 540, 325-332 (2005)

16) He, M., Hu, B., Zeng, Y. and Jiang, Z., J. Alloys Compd., 390, 168-174(2005)

17) Sakamoto, N., Kano, N. and Imaizumi, H., Bioinorg. Chem. Application, Vol. 2008, 8 pages, Article ID
706240 (2008) (doi:10.1155/2008/706240)

18) Seki, H. and Suzuki, A., J. Colloid Interface Sci., 206, 297-301 (1998)

19) Yang, J. and Volesky, B., Environ. Sci. Technol., 33, 751-757 (1999)

20) Diniz, V. and Volesky, B., Water Res., 39, 239-247 (2005)

21) Sakamoto, N., Kano, N. and Imaizumi, H., Appl. Geochem., 23, 2955-2960 (2008)

22) Charlot, G. (Translated by Sone, K. and Tanaka, M.), Teisei Bunsekikagaku(Qualitative Analytical Chemistry), pp.257-262, pp.268-273, Kyoritsu Syuppan, Tokyo (1958) (in Japanese)

23) Davis, T.A., Volesky, B. and Vieira, R. H. S. F., Water Res., 34, 4270-4278(2000)

24) Hashim, M. A. and Chu, K. H., Chem. Eng. J., 97, 249-255 (2004)

25) Sheng, P. X., Ting, Y. P., Chen, J. P. and Hong, L., J. Colloid Interface Sci., 275, 131-141 (2004) 
要旨

\title{
3 種類の海藻バイオマスを用いたランタニド元素の生物吸着
}

\author{
坂本信生, 狩野直樹*, 王 玉丹, 高 立娣, 今泉 洋* \\ 新潟大学大学院自然科学研究科 \\ *新潟大学工学部 \\ 950-2181 新潟県新潟市西区五十嵐二の町 8050
}

\begin{abstract}
海藻バイオマスの希土類元素（REEs）に対する吸着剤としての有効性を検証するため, Ca で置 換した 3 種類の海藻（褐藻のイソモク，紅藻のベニスナゴ，緑藻のアナアオサ）の乾燥試料を用い て, 既知量のランタニド元素（La, Euあるいは $\mathrm{Yb}$ ) を含んだ水溶液中からの吸着実験を単一成分 系で行った。更に, 得られたデー夕を, Langmuir 吸着等温式や Freundlich 吸着等温式に適用す ることにより, 吸着除去メカニズムを検討した。また, 走査電子顕微鏡（SEM）により, 各試料 の金属吸着前後のそれぞれの表面状態について比較検討し，本研究で用いた貝殼の特性を考察した。

その結果, 主として以下のことが明らかになった。(1) 褐藻のイソモク, 緑藻のアナアオサでは, 金属吸着前後で表面形状の変化がほとんど見られなかったのに対し，紅藻のベニスナゴでは見られ た。（2）海藻バイオマスによるランタニド元素の吸着は, Langmuir 及び Freundlich 吸着等温線 に十分に適応する。特に Langmuir 等温線により適合することから, 単分子層による吸着が支配的 と言える。（3）海藻バイオマスは，REEsの有用な吸着剤となりうる。特に緑藻のアナアオサは, La 除去に打ける有望な吸着剤といえる。(4) 海藻バイオマスによるランタニド元素の吸着におい ては,イオン交換が主要なメカニズムであると考えられる。
\end{abstract}

